\title{
THE FUTURE OF THE SECOND AMENDMENT IN A TIME OF LAWLESS VIOLENCE
}

\author{
Nelson Lund
}

\begin{abstract}
Professors Reva B. Siegel and Joseph Blocher have focused attention on an underappreciated dimension of the debate about the constitutional right to keep and bear arms. They reject a narrow concept of "public safety" that evaluates regulations solely in terms of physical safety, without adequately recognizing the public's interest in securing "a foundation for community and for the exercise of many of our most cherished constitutional liberties." At this level of generality, I agree. But I do not agree that an appropriately broad conception of public safety should widen the discretion of legislatures to impose restrictions on firearms.

The issue that Professors Siegel and Blocher raise is especially important during this time of politically inspired riots and flaccid government responses to mob violence. The most practically important Second Amendment issue that is ripe for Supreme Court resolution concerns the scope of the constitutional right to bear arms in public. The Constitution's text and history offer little direct guidance, and the Justices will inevitably have to decide how to resolve the conflicts of interest that occur when governments seek to promote public safety by depriving individuals of the means to protect themselves.

This Essay argues that the single most foundational principle on which our liberal regime rests is the inherent right of self-defense against violent assaults, whether from common criminals or political activists or tyrannical governments. The Second Amendment's core purpose is to insulate that right from improper government interference. But protecting the right to keep and bear arms also serves a broader civic purpose. An armed citizenry displays the spirit of courage and self-reliance on which genuine self-government depends. That spirit should be honored and defended more than ever in times of civil unrest and especially when governments have responded to mob violence with passive acceptance or with perverse encouragement.
\end{abstract}

AUTHOR-University Professor, Antonin Scalia Law School, George Mason University. I am grateful to Robert Leider, Jack Lund, and Alice Ristroph for helpful comments on an early draft, to Jacob Meckler for useful 
research assistance, and to Scalia Law School's Liberty and Law Center for research support.

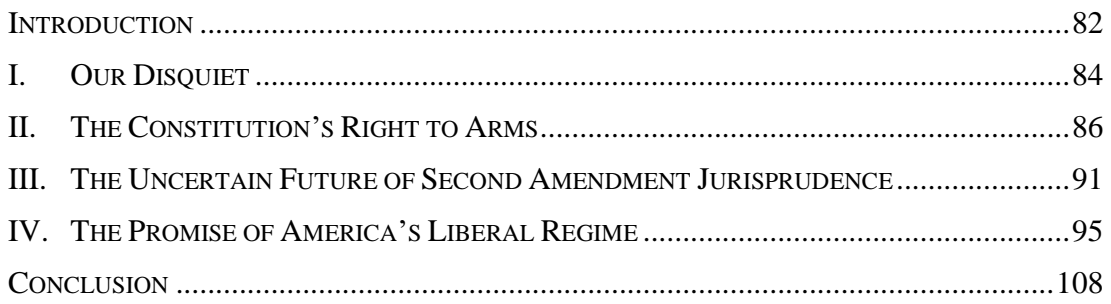

\section{INTRODUCTION}

Just over eleven years ago, in a dissent from the Supreme Court's decision that the Fourteenth Amendment makes the Second Amendment applicable to the state governments, Justice John Paul Stevens wrote:

Guns may be useful for self-defense, as well as for hunting and sport, but they also have a unique potential to facilitate death and destruction and thereby to destabilize ordered liberty. Your interest in keeping and bearing a certain firearm may diminish $m y$ interest in being and feeling safe from armed violence. $^{1}$

None of his colleagues joined this dissent. After he retired from the Court, Justice Stevens advocated that the Constitution's Second Amendment be repealed. ${ }^{2}$ It may therefore be tempting to dismiss his comment in dissent as an emotional interjection with no legitimate bearing on constitutional interpretation. That would be a mistake. Professors Reva B. Siegel and Joseph Blocher have recently sharpened and developed Justice Stevens's concern. ${ }^{3}$ In doing so, they have focused on an underappreciated dimension of the debate about the constitutional right to keep and bear arms. It is universally accepted that the government has a compelling interest in what is called "public safety." Professors Siegel and Blocher observe that judges often recite this truism "without full consideration of what is encompassed in that concept - freedom from intimidation, for example, not just physical pain."5 This habit reflects a more general tendency to evaluate gun-control

\footnotetext{
${ }^{1}$ McDonald v. City of Chicago, 561 U.S. 742, 891 (2010) (Stevens, J., dissenting).

2 John Paul Stevens, Repeal the Second Amendment, N.Y. TIMES (Mar. 27, 2018), https://www. nytimes.com/2018/03/27/opinion/john-paul-stevens-repeal-second-amendment.html [https://perma.cc/ 43T4-FBU2].

${ }^{3}$ See Reva B. Siegel \& Joseph Blocher, Why Regulate Guns?, 48 J.L., MED. \& ETHICs 11, 11 (2020).

4 See, e.g., Kachalsky v. County of Westchester, 701 F.3d 81, 97 (2d Cir. 2012) (collecting cases).

5 Siegel \& Blocher, supra note 3, at 11.
} 
regulations in terms of a narrow cost-benefit analysis: if a given regulation is thought likely to prevent more deaths and physical injuries than it causes, it is often considered a reasonable public safety measure. ${ }^{6}$

Professors Siegel and Blocher argue that an excessive focus on this kind of analysis reflects an impoverished view of the public interest. ${ }^{7}$ They state: "'Public safety' is a social good: it includes the public's interest in physical safety as a good in itself, and as a foundation for community and for the exercise of many of our most cherished constitutional liberties." 8

At this level of generality, I agree. However, I disagree with Professors Siegel and Blocher's claim that an appropriately broad conception of public safety and constitutional values should translate to broad discretion for legislatures to impose restrictions on the freedom to keep and bear arms. On the contrary, as I argue in this Essay, a sound understanding of the public interest should make courts especially skeptical of gun regulations. That skepticism should be brought to bear in all cases, including those involving regulations that are aimed at promoting feelings of safety rather than actual physical safety. In such cases, cost-benefit analysis can make a useful contribution to a sound jurisprudence. But there is also a broader and longerterm interest of the public in the preservation of a robust right to keep and bear arms.

The right to keep and bear arms, and to use them when appropriate, is not an outmoded relic of a frontier society. Our Founders included the Second Amendment in the Constitution for reasons that had deep roots in their understanding of both the purpose of government and the need to impose constitutional limits on government. The Amendment was expected to help prevent political oppression, but it also guards against oppression imposed by criminal violence that the government cannot or will not prevent. The vital importance of the right to possess arms for personal self-defense can be easy to overlook or forget, especially when widespread criminal violence threatens both liberty and safety. The temptation to trade freedom

\footnotetext{
${ }^{6}$ In his dissenting opinion in District of Columbia v. Heller, for example, Justice Stephen Breyer concluded that the legislative body had made a reasonable judgment that a ban on handguns would likely reduce deaths and injuries, by which he could only have meant that the regulation was reasonably expected to cause a net reduction in those harms (whether the additional deaths that the regulation might be expected to cause was zero or some small number). 554 U.S. 579, 693-705 (2008) (Breyer, J., dissenting). Some lower courts have used this kind of cost-benefit analysis to resolve the constitutionality of gun regulations. See, e.g., Kachalsky, 701 F.3d at 96-99 (upholding restriction on carrying firearms in public); Drake v. Filco, 724 F.3d 426, 437-40 (3d Cir. 2013) (same); Heller v. District of Columbia (Heller II), 670 F.3d 1244, 1262-64 (2011) (upholding ban on large-capacity magazines and certain semiautomatic rifles).

7 See Siegel \& Blocher, supra note 3, at 12.

${ }^{8}$ Id. at 11 .
} 
for governmental promises of safety may be even more alluring when such violence takes the form of sustained and repeated riots that reflect a serious breakdown of public order.

The Second Amendment also plays a significant role in fostering the kind of civic virtue that resists the urge to rely on the government for one's well-being. Armed citizens take responsibility for their own safety, thereby exhibiting and cultivating the self-reliance and vigorous spirit that are ultimately indispensable for genuine self-government.

Adjudicating Second Amendment cases often requires judges to balance interests that politicians find compelling against the interests of individuals who resist infringements on their freedom. And that is true whether or not the judges conduct this balancing openly. ${ }^{9}$ In order to carry out that duty in a way that reflects the balance of interests the people chose when they enacted the Second Amendment, judges need a sound understanding of the Amendment's purposes. Whatever questions are left open by the constitutional text and its legislative history, and there are many, judges should give no weight to unsubstantiated fears about the dangers supposedly posed by an armed populace. Nor should they ever forget the long-term value of republican virtues that are fostered by a robust right to keep and bear arms.

Part I of this Essay explains why the recent civil unrest could have significant effects on the future of the right to keep and bear arms. Part II briefly discusses the background to the Supreme Court's nascent Second Amendment jurisprudence. Part III describes two different interpretive approaches that have emerged in the lower courts. Part IV takes a broader look at the fundamental principles of our liberal republic. Those principles, this Essay argues, should help guide the courts in cases where the constitutional text and legislative history leave them with discretion in balancing the conflicting interests that are often at stake in Second Amendment cases.

\section{OUR DISQUIET}

America has lately experienced an extraordinary plague of violent political unrest. Much of the political violence in recent years has been connected to specific allegations of police misconduct and to broader claims about pervasive racial bias in the use of lethal force by law enforcement. Most dramatically, the nation was swept by mass protests, beginning in late May 2020, which responded to incidents in which such bias was imputed to police officers who were involved in confrontations that turned violent. No

9 See infra Part III. 
one knows what mixture of fact and fiction drove the protests, but we do know that many of the demonstrations were marked by arson, looting, beatings, and murders of innocent victims.

Most strikingly, some state and local governments were visibly tolerant of the rioters. ${ }^{10}$ Public officials discouraged or forbade the use of standard crowd-control measures and in some cases prevented the police from taking action to protect innocent bystanders or their property. One city experienced nightly riots for months on end. Another simply surrendered an area within its legal jurisdiction to insurrectionists who attacked a police station and declared the area to be a police-free zone. In some cases, prosecutors were disinclined to enforce the law against individuals who had been arrested. Prominent politicians promoted the "defunding" of the police, and some jurisdictions took concrete steps in that direction. Violent crime spiked sharply in some places, probably in part because the police became less aggressive in enforcing the law. ${ }^{11}$

This episode may eventually prove to have been a temporary phenomenon. Perhaps government tolerance for mob violence, and for rising rates of other violent crimes, will become so politically unpopular that public officials will respond more firmly than they did in 2020. But it is not impossible that we will experience a prolonged period of intermittent civil unrest that leaves a significant fraction of the population in a durable state of heightened insecurity. It is also at least conceivable that the unrest will get a lot worse, especially if we experience a sustained economic decline, linked perhaps to exogenous shocks like the COVID-19 pandemic. Even if the political disquiet subsides, new restraints on the police may lead to dramatically higher levels of criminal violence in the poorest and most vulnerable neighborhoods. ${ }^{12}$ A number of unprovoked mass shootings have also occurred recently..$^{13}$ Although such incidents make up a tiny fraction of

\footnotetext{
${ }^{10}$ For a discussion of the events during the summer of 2020 recounted in this paragraph, see, for example, David E. Bernstein, The Right to Armed Self-Defense in Light of Law Enforcement Abdication, 19 GEO. J.L. \& PUB. POL'Y 177, 185-202 (2021).

11 See Paul G. Cassell, Explaining the Recent Homicide Spikes in U.S. Cities: The "Minneapolis Effect" and the Decline in Proactive Policing, 33 FED. SENT'G REP. 83 (2020).

12 See id.

13 See generally Daniel Victor \& Jenny Gross, A List of Recent Mass Shootings in the United States, N.Y. TiMES (Apr. 16, 2021), https://www.nytimes.com/2021/03/23/us/us-mass-shootings.html [https://perma.cc/MQG2-VK3X] (providing a chronological list and descriptions of mass shootings in the United States since 2016).
} 
the murders that occur each year, ${ }^{14}$ they attract a great deal of attention from the media and from politicians.

Whatever happens politically in response to riots, mass shootings, and rising crime rates, the courts are almost certain to find themselves confronted with Second Amendment cases that call for serious attention to the competing interests described by Justice Stevens. The threat posed by widespread public violence, whether politically motivated or not, may induce legislatures to adopt new regulations aimed at restricting civilians' use of firearms. It may also provoke more aggressive enforcement of existing restrictions.

All of this comes at a time when the Supreme Court's nascent Second Amendment jurisprudence is at an important inflection point. So far, the Court has held only that the Constitution protects the narrow right to keep a handgun in one's home for self-protection. The most practically important questions that have not yet been answered have to do with carrying firearms in public. The Justices have suggested that they will recognize such a right, ${ }^{15}$ but they have not decided how far legislatures may go in restricting it. In setting those limits, they will inevitably engage in some kind of interestbalancing. This Essay seeks to help clarify the appropriate balance of interests that is implied by the Constitution. It is this balance that the Court should strive to recognize in its Second Amendment decisions.

\section{The CONSTITUTION'S Right TO ARMS}

The right to keep and bear arms has a long history in our civilization. In 1689, it was codified in the English Bill of Rights, formalizing and perhaps transforming an element of that nation's militia tradition. ${ }^{16}$ After our revolutionary secession from Great Britain, four of the original American

\footnotetext{
14 Bonnie Berkowitz \& Chris Alcantara, The Terrible Numbers that Grow with Each Mass Shooting, WASH. Post (May 10, 2021), https://www.washingtonpost.com/graphics/2018/national/mass-shootingsin-america/ [https://perma.cc/F6UZ-XLP4]; see also Dan Gross, I Helped Lead the Gun Control Movement. It's Asking the Wrong Questions., N.Y. TIMES (Apr. 8, 2021), https://www.nytimes.com/ 2021/04/08/opinion/politics/i-helped-lead-the-gun-control-movement-its-asking-the-wrong-questions. html [https://perma.cc/CX8B-TETS].

15 Heller, for example, contains a lengthy rebuttal of the claim that the term "bear Arms" in the Second Amendment refers only to military service, which concludes by declaring that the text "guarantee[s] the individual right to possess and carry weapons in case of confrontation." District of Columbia v. Heller, 554 U.S. 570, 584-92 (2008). The opinion also contains an approving dictum about laws that forbid "the carrying of firearms in sensitive places such as schools and government buildings," $i d$. at 626 , which suggests that there is a right to carry them in some other places. And the Court seemed to approve of bans on concealed carry, $i d$., without suggesting that government may simultaneously ban both concealed and open carry.

16 See Joyce Lee Malcolm, To Keep and Bear Arms: The Origins of AN ANGLO-AmericAn RIGHT 114-22 (1994).
} 
states expressly codified the right in their constitutions, and ten more did so by $1820 .{ }^{17}$ In 1791, the American people adopted the Second Amendment, which protects the right against infringement by the national government. There is significant evidence, though it is hardly conclusive, that the Fourteenth Amendment, adopted in 1868, was meant to protect the right to keep and bear arms (as well as other rights) against infringement by state and local governments. ${ }^{18}$ And today, forty-four state constitutions contain a provision protecting this right. ${ }^{19}$

Despite its long historical pedigree, and perhaps in part because of it, the scope of the right to arms is in many respects indeterminate. It has been formulated differently at various times and always with significant vagueness and ambiguity. Consider, for example, the text of the Second Amendment, which has proved to be particularly controversial:

A well regulated Militia, being necessary to the security of a free State, the right of the people to keep and bear Arms, shall not be infringed.

Whatever else this provision may mean, it originally put limits only on the federal government, so the states were generally left to regulate weapons as they saw fit. ${ }^{20}$ Because the federal government did not get into the business of gun control until the twentieth century, the Second Amendment had little direct practical effect for a long time.

After the Civil War, significant new restrictions were placed on the states by the Fourteenth Amendment. The text of that provision says nothing about the right to keep and bear arms, but it does say that "[n]o State shall make or enforce any law which shall abridge the privileges or immunities of citizens of the United States." Soon after the Amendment was ratified, the Supreme Court held that this Clause protects only those rights that "owe their existence to the Federal government, its National character, its Constitution, or its laws." ${ }^{21}$ As Justice Stephen Johnson Field's dissent pointed out, this seemed to deprive the Clause of any real effect because the state

17 See Eugene Volokh, State Constitutional Rights to Keep and Bear Arms, 11 TEX. REV. L. \& POL. 191, 208-09 (2006).

18 See McDonald v. City of Chicago, 561 U.S. 742, 833-38 (2010) (Thomas, J., concurring in part and concurring in the judgment); see also Nelson Lund, Two Faces of Judicial Restraint (or Are There More?) in McDonald v. City of Chicago, 63 FLA. L. REV. 487, 506-08 (2011) [hereinafter Lund, Two Faces of Judicial Restraint] (summarizing, and casting some doubt on, Justice Thomas's analysis in McDonald).

19 See Volokh, supra note 17, at 206-07; State Constitutional Protections, SECOND AMEND. FOUND., https://www.saf.org/state-constitutional-protections-2/ [https://perma.cc/V5QY-HZK7].

20 See Barron v. Mayor of Baltimore, 32 U.S. (7 Pet.) 243, 250 (1833). Congress may, of course, preempt some state restrictions on firearms by exercising its Article I powers over the militia. See U.S. CONST. art. I, $\S 8$, cl. 15 .

21 Slaughter-House Cases, 83 U.S. (16 Wall.) 36, 79 (1873). 
governments were already forbidden to violate rights protected by the federal Constitution and laws. ${ }^{22}$ United States $v$. Cruikshank then held that the right protected by the Second Amendment is not among the privileges or immunities of citizens of the United States. ${ }^{23}$ This conclusion is odd on its face, given that the right to keep and bear arms is expressly protected by the Constitution. But the Court declared that the right, although protected by the Second Amendment from federal infringement, is not protected by the Privileges or Immunities Clause because it was not created by the federal Constitution. ${ }^{24}$

In a series of cases during the twentieth century, the Supreme Court decided to apply selected provisions of the Bill of Rights to the states after all. ${ }^{25}$ But rather than revisit Cruikshank, the Court relied in these cases on the Fourteenth Amendment's Due Process of Law Clause. ${ }^{26}$ On its face, this application of "substantive due process" adds to the oddity of the Fourteenth Amendment jurisprudence generated by Cruikshank. The Court has never explained how the text or original meaning of the Due Process of Law Clause "incorporated" certain parts of the Bill of Rights, i.e., made them applicable to the states. In another questionable doctrinal move, the Justices decided that rights that were thus incorporated into the Fourteenth Amendment have exactly the same meaning and scope as the rights directly protected by the Bill of Rights, whether or not those rights were understood in the same way in 1791 and $1868 .{ }^{27}$

The Supreme Court's first major Second Amendment decision, District of Columbia v. Heller, held that the Second Amendment forbids the federal government to ban the possession of handguns in the home. ${ }^{28}$ The opinion in this case suffers from a number of analytical and jurisprudential flaws, ${ }^{29}$ but it correctly resolved two important threshold issues. First, the Second Amendment protects an individual right, not a right belonging to states or

\footnotetext{
${ }^{22} I d$. at 96 (Field, J., dissenting).

2392 U.S. 542, 553 (1876).

${ }^{24} \mathrm{Id}$.

25 The cases are briefly reviewed in McDonald v. City of Chicago, 561 U.S. 742, 763-66 (2010) (plurality opinion).

${ }^{26} I d$. at 763.

27 See id. at 765.

28554 U.S. 570, 635 (2008). The Court also included an unexplained series of dicta endorsing several gun-control laws that were not before the Court. Id. at 624, 626-27.

29 See Nelson Lund, The Second Amendment, Heller, and Originalist Jurisprudence, 56 UCLA L. REV. 1343, 1349-56 (2009) [hereinafter Lund, Originalist Jurisprudence].
} 
state militias. ${ }^{30}$ Second, the core purpose of the right is to secure the natural or inherent right of self-defense. ${ }^{31}$ The Court's application of these principles to the issue of handguns in the home was poorly reasoned, but its conclusion is eminently defensible. ${ }^{32}$ And most importantly, the purpose of the Second Amendment implies that courts should establish a presumption against the constitutionality of regulations that restrict the freedom of American citizens to keep and bear arms. ${ }^{33}$

Two years after Heller, McDonald v. City of Chicago added the Second Amendment to the other Bill of Rights provisions that the Court will apply against the states. ${ }^{34}$ The McDonald plurality opinion relied for this conclusion on precedents holding that the Due Process of Law Clause protects rights that are fundamental to our scheme of ordered liberty and are "deeply rooted in this Nation's history and tradition." 35 Justice Clarence Thomas, who concurred in the judgment, would have reconsidered Cruikshank's interpretation of the Privileges or Immunities Clause, but none of the other Justices agreed. ${ }^{36}$

The plurality's reliance on precedent was no surprise. The text of the Fourteenth Amendment is vague, and its legislative history is notoriously prolix and variegated, but the deep roots of the right to arms in our history is beyond dispute. Serious students of the historical materials have come to multiple, mutually inconsistent conclusions about the meaning of the Privileges or Immunities Clause and about the validity, as an original matter, of the incorporation thesis. ${ }^{37}$ At this point in history, it is unlikely that the

\footnotetext{
30 See Nelson Lund, The Past and Future of the Individual's Right to Arms, 31 GA. L. REV. 1, 19-39 (1996) [hereinafter Lund, Past and Future]; Nelson Lund, D.C. 's Handgun Ban and the Constitutional Right to Arms: One Hard Question?, 18 GEO. MASON U. C.R.L.J. 229, 236-45 (2008) [hereinafter Lund, D.C. 's Handgun Ban].

31 See Lund, Originalist Jurisprudence, supra note 29, at 1373; Lund, D.C. 's Handgun Ban, supra note 30 , at $245-49$.

32 See Lund, Originalist Jurisprudence, supra note 29, at 1355-56, 1375-76.

33 See Heller, 554 U.S. at 628 n.27; Lund, Originalist Jurisprudence, supra note 29, at 1372-75.

34561 U.S. 742, 791 (2010) (plurality opinion); id. at 805 (Thomas, J., concurring in part and concurring in the judgment).

35 Id. at 758-59, 768, 780-91 (plurality opinion) (quoting Washington v. Glucksberg, 521 U.S. 702, 721 (1997)).

36 See id. at 833-38 (Thomas, J., concurring in part and concurring in the judgment). For some doubts about the validity of the originalist arguments set forth in Justice Thomas's opinion, see Lund, Two Faces of Judicial Restraint, supra note 18, at 506-08; Philip Hamburger, Privileges or Immunities, 105 Nw. U. L. REV. 61, 145 n.305 (2011).

37 No serious scholar thinks that the original meaning of any provision other than the Privileges or Immunities Clause could imply incorporation of the right to keep and bear arms. For a sample of interpretations of that Clause, see John Harrison, Reconstructing the Privileges or Immunities Clause, 101 YALE L.J. 1385, 1416-20 (1992) (arguing that the Clause is an antidiscrimination provision modeled
} 
Supreme Court will abandon its dubious due process selective-incorporation jurisprudence in favor of a search for the Fourteenth Amendment's genuine original meaning. Incorporation may therefore be taken as a given in discussions about the Second Amendment's future in the courts.

Although the Court's incorporation doctrine is not based on an account of the original meaning of the Constitution, the historical context of the Fourteenth Amendment can help illuminate the spirit in which courts should approach difficult questions involving the regulation of guns. Whatever serious questions there may be about its original meaning, no one doubts, for example, that the Fourteenth Amendment was meant to help secure the freedmen from the oppressive regulations imposed by the Black Codes..$^{38}$ Discriminatory gun regulations, moreover, constituted one especially objectionable feature of those laws. ${ }^{39}$ After the federal government withdrew its troops from the former Confederate states in 1877, the subordination of the freedmen was reestablished. ${ }^{40}$ The ensuing decades saw a great deal of technically or seemingly private violence by the Ku Klux Klan and similar groups as well as more spontaneous outbreaks of terrorism..$^{41}$ Much of this

on the Comity Clause of Article IV); ILAN Wurman, THE SECOND Founding: AN InTroduction to THE FouRTEENTH AMENDMENT 102-03 (2020) (interpreting the Clause to mean that the states "had to accord all [privileges and immunities] equally without arbitrary discrimination"); Hamburger, supra note 36 , at 122, 125 (arguing that the Clause is an antidiscrimination provision that was meant to overrule Dred Scott's holding and to establish that Comity Clause rights enforceable by Congress belong to all citizens of the United States); and KuRT T. LASH, THE FourTEENTH AMENDMENT AND THE PRIVILEGES AND IMMUNITIES OF AMERICAN CitizENSHIP, at xi (2014) (arguing that the Clause was modeled on antebellum treaties and was meant to protect national privileges and immunities).

With respect to the scope of rights protected by the Clause, see $i d$. (arguing that all rights enumerated in the Constitution are protected, but nothing else); AKHIL REED AMAR, THE BILL OF RIGHTS: CREATION AND RECONSTRUCTION 215-30 (1998) (maintaining that personal privileges enumerated in the Constitution are protected, but some of them are thereby transformed); Hamburger, supra note 36, at 71, 146 (concluding that the Clause does not protect substantive rights as such but rather "responded to a dispute about discrimination that was prominent in the antislavery struggle"); WURMAN, supra at 11, 104-05 (arguing that the Clause does not protect substantive rights as such but rather is an antidiscrimination provision requiring equality in the provision of civil rights accorded to citizens); RANDY E. BARNETT, Restoring THE Lost CONSTITUTION: THE PRESUMPTION OF LIBERTY 66-68 (rev. ed. 2014) (arguing that the provision protects an unenumerated collection of fundamental rights); and Randy E. Barnett \& Evan D. Bernick, The Difference Narrows: A Reply to Kurt Lash, 95 NOTRE DAME L. REV. 679, 684 (2019) (asserting that rights enumerated in the first eight Amendments are protected).

${ }^{38}$ See, e.g., Stephen P. Halbrook, That Every Man Be Armed: The Evolution of a CONSTITUTIONAL Right 108-09 (1984) (listing examples of "black code provisions" which "prompted initiation of civil rights legislation that culminated in the proposal of the Fourteenth Amendment").

39 See Stephen P. Halbrook, Freedmen, the FourteEnth Amendment, and the Right to BEAR ARMS, 1866-1876, at 1-3 (1998).

${ }^{40}$ See Robert J. Cottrol \& Raymond T. Diamond, The Second Amendment: Toward an AfroAmericanist Reconsideration, 80 GeO. L.J. 309, 348 (1991); STEPHAN THERnSTROM \& ABIGAIL THERNSTROM, AMERICA In BLACK AND White: ONE NATION, INDIVISIBLE 25-30 (1997).

41 Cottrol \& Diamond, supra note 40, at $348,351$. 
violence was tolerated and often encouraged by governments in several states. ${ }^{42}$

Although the Jim Crow period's toxic brew of official and unofficial forms of oppression was successful in subjecting the former slaves and their descendants to political subordination, this community maintained a tradition of armed self-defense. ${ }^{43}$ That tradition, which has not disappeared today, ${ }^{44}$ existed within and because of a wider tradition of respect for the principle that armed resistance to illegal violence is one distinctive mark of a free people. In a statement with implications that go well beyond its immediate context, Dr. Martin Luther King Jr. said:

Violence exercised merely in self-defense, all societies, from the most primitive to the most cultured and civilized, accept as moral and legal. The principle of self-defense, even involving weapons and bloodshed, has never been condemned, even by Gandhi .... When the Negro uses force in self-defense, he does not forfeit support - he may even win it, by the courage and self-respect it reflects..$^{45}$

Such courage and self-respect deserve support today for the same reasons that inspired Dr. King to expect these virtues to assist a politically oppressed group that was fighting for its freedom.

\section{THE UNCERTAIN FUTURE OF SECOND AMENDMENT JURISPRUDENCE}

District of Columbia v. Heller holds only that the Second Amendment protects the right to keep a handgun in one's home for self-defense. ${ }^{46}$ The majority opinion provides very little guidance about the proper resolution of cases involving less sweeping regulations than the D.C. handgun ban. The Court's lengthy exploration of historical sources primarily supports two threshold conclusions: that the right to keep and bear arms is an individual, private right (rather than a right to establish or serve in a militia) and that the purpose of the right is to protect the freedom to use arms for the core lawful purpose of self-defense. Heller says almost nothing about the scope of the right, apart from some unsupported dicta provisionally approving a few politically popular gun-control regulations. ${ }^{47}$

\footnotetext{
42 See id. at 348-51.

43 See Nicholas Johnson, Negroes and the Gun: The Black Tradition of Arms 13 (2014).

44 See, e.g., Derek Major, Black Guns Matter Group Is Teaching Black Americans How to Use Firearms, BLACK ENTER. (July 16, 2020), https://www.blackenterprise.com/black-guns-matter-group-isteaching-black-americans-how-to-use-firearms/ [https://perma.cc/L7EQ-3WXW].

45 JoHnson, supra note 43, at 27 (quoting King).

46554 U.S. 570, 635 (2008).

47 See id. at 626-27. For a critique of these dicta, see Lund, Originalist Jurisprudence, supra note 29 , at $1356-68$
} 
The Court forbade the use of rational basis review and criticized Justice Stephen Breyer's dissent for what the majority called a "freestanding 'interest-balancing' approach." 48 The precise holding in the case was not supported with any historical evidence or with the kind of means-end analysis required for the application of heightened scrutiny. ${ }^{49}$ But the Court did not rule out the use of heightened scrutiny in future cases. Instead, the Court simply announced that the handgun ban would be judged unconstitutional under either strict or intermediate scrutiny. ${ }^{50}$ The Court's only explanation for extending constitutional protection to handguns in particular was that they are very popular with the American public today for reasons that made sense to the Court. ${ }^{51}$

Because Heller provides almost no clear guidance about the scope of the right to keep and bear arms, future Courts could easily confine the decision to its facts and effectively reduce the Second Amendment to insignificance. Or they could aggressively protect the right in much the same way that the Court has protected the freedom of speech for many decades. Or something in between. What future Courts will not be able to do, in my opinion, is to fashion a workable jurisprudence that avoids engaging in interest-balancing, as the Heller Court seemed to suggest that it could. ${ }^{52}$ For that reason, a full appreciation of the importance of the right to keep and bear arms may be a necessary condition for the development of a body of case law that faithfully reflects the purposes of the Second Amendment.

Since Heller and McDonald were decided, the lower courts have developed somewhat different interpretive approaches. Most courts have used a two-step legal test to determine whether a challenged regulation

\footnotetext{
48 Heller, 554 U.S. at 628 n.27, 634-35.

49 The forms of means-end scrutiny that are applied when rational basis review is inapplicable have been described in various ways. Strict scrutiny is often said to require the government to show that a regulation serves a compelling government interest by "the least restrictive means." See McCullen v. Coakley, 573 U.S. 464, 478 (2014). A lower level of scrutiny, frequently called "intermediate scrutiny," is typically said to require that a substantial or important government interest be served by a restriction that "is no greater than is essential to the furtherance of that interest." See Turner Broad. Sys., Inc. v. FCC, 512 U.S. 622, 662 (1994) (quoting United States v. O’Brien, 391 U.S. 367, 377 (1968)). For a useful discussion of means-end analysis in the Second Amendment context, see Ezell v. City of Chicago, 651 F.3d 684, 699-703 (7th Cir. 2011).

${ }^{50}$ Heller, 554 U.S. at $628-29$.

51 Id. at 629.

52 See id. at 635. For further discussion, see Lund, Originalist Jurisprudence, supra note 29, at 135256, 1368-69, 1372-76 (criticizing Heller's explanation of the Court's holding and advocating that the original purpose of the Second Amendment be used to guide courts on issues that cannot be reliably resolved by the Constitution's text and history alone), and Nelson Lund, Second Amendment Standards of Review in a Heller World, 39 FORDHAM URB. L.J. 1617, 1629 (2012) ("Covert interest-balancing dressed up as an analysis of history and tradition is no better than more straightforward interest-balancing in the form of strict or intermediate scrutiny, and almost certainly worse.").
} 
violates the Second Amendment. First, the court asks whether the regulation "imposes a burden on conduct falling within the scope of the Second Amendment's guarantee." ${ }_{53}$ If it does, the court will apply "some form of means-end scrutiny." ${ }_{54}$

The vast majority of decisions have upheld the challenged regulations, usually under the rubric of intermediate scrutiny or through reliance on dicta in Heller that endorsed certain regulations. Typically, the court finds that the government's goal is significant, substantial, or important and that the means chosen to advance that goal are reasonable, even if there is an imperfect fit between the means and the end. ${ }^{55}$ Not all of these decisions have been unanimous, and a few regulations have been invalidated. In practice, however, the standard two-part test has largely operated as a formula for upholding gun regulations. The resulting case law looks a lot like an effective if unacknowledged use of the rational basis test that Heller rejected. ${ }^{56}$

A different approach has occasionally been used. The D.C. Circuit, for example, invalidated a law that imposed a nearly total ban on carrying weapons in public for self-defense. ${ }^{57}$ Such a law effectively reads the word "bear" out of the Constitution, and the court thought that the Second Amendment's text and history, as interpreted by the Supreme Court in Heller, were sufficient to condemn it, without recourse to means-end analysis..$^{58}$

Like Heller's treatment of the threshold questions about the nature and purpose of the Second Amendment right, the use of text and history to

53 The seminal opinion is United States v. Marzzarella, 614 F.3d 85, 89 (3d Cir. 2010).

54 Id.

55 For reviews of the case law discussed in this paragraph, see SARAH HERMAN PECK, CONG. RSCH. SERV., R44618, PoST-Heller SECOND AmEndment JuRISPRUdEnCE (2019); David B. Kopel \& Joseph G.S. Greenlee, The Federal Circuits' Second Amendment Doctrines, 61 ST. LouIS U. L.J. 193 (2017); David B. Kopel \& Joseph G.S. Greenlee, Federal Circuit Second Amendment Developments 2017-2018 (Univ. of Denver Sturm Coll. of L. Legal Studies Research Paper No. 18-29, 2018), https://ssrn.com/a=3227193 [https://perma.cc/C9LX-QZNQ].

56 See Heller, 554 U.S. at 628 n.27. For discussions on the blurry line between rational basis review and intermediate scrutiny in Second Amendment cases, see Silvester v. Becerra, 138 S. Ct. 945,945 (2018) (Thomas, J., dissenting from the denial of certiorari); Allen Rostron, Justice Breyer's Triumph in the Third Battle over the Second Amendment, 80 GEO. WASH. L. REV. 703, 706-07 (2012); and Nelson Lund, The Proper Role of History and Tradition in Second Amendment Jurisprudence, 30 U. FLA. J.L. \& PuB. PoL'y 171, 179-80, 180 n.60 (2020) [hereinafter Lund, Proper Role].

57 Wrenn v. District of Columbia, 864 F.3d 650, 667 (D.C. Cir. 2017).

58 See id. at 667-68; see also Young v. Hawaii, 896 F.3d 1044, 1069-71 (9th Cir. 2018) (relying on text and history to invalidate such a law without conducting a means-ends analysis), vacated en banc, 992 F.3d 765 (9th Cir. 2021), petition for cert. filed, No. 20-1639 (May 25). An Illinois law that imposed a virtually total ban on carrying a gun for self-defense outside the home was invalidated because the court interpreted Heller to require that result absent a greater showing of evidence that the ban would increase public safety. Moore v. Madigan, 702 F.3d 933, 942 (7th Cir. 2012). 
establish that the Constitution protects a meaningful right to bear arms in public is easily defensible. ${ }^{59}$ But very few regulations effectively eliminate the right to keep or bear arms for the purpose of self-defense. Instead, guncontrol laws typically restrict who may be armed, or what kinds of arms civilians may have, or where they may take their weapons, or how they may lose their rights.

Are the Constitution's text and legislative history sufficient to evaluate the constitutionality of these more limited restrictions on the freedom to keep or bear arms? When he was on the D.C. Circuit, then-Judge Brett Kavanaugh wrote a dissenting opinion in which he rejected the use of means-end analysis in evaluating a relatively narrow ban on certain semiautomatic rifles and on large-capacity ammunition magazines. ${ }^{60}$ In my view, the historical record is far too sparse to provide sufficient guidance about the constitutionality of regulations like those at issue in this case. Similar regulations had not been adopted by any American government before $1791,{ }^{61}$ and only a narrow range of restrictions, primarily involving concealed carry, had become fairly common in the era during which the Fourteenth Amendment was adopted. ${ }^{62}$ Was this because of a consensus that restrictions of the kind that are now politically popular were unconstitutional? Or was it because there was just no political demand for regulations that would have been considered permissible if they had been adopted? The historical record will seldom offer more than hints at what the right answer is. Not surprisingly, Judge Kavanaugh relied primarily on his interpretation of Heller, rather than on probative evidence from the historical record. ${ }^{63}$

The means-end approach, which Judge Kavanaugh rejected, is also less than satisfactory. It typically consists of balancing the asserted interests of the government against the interests of those who challenge the government's regulations. When judges must engage in interest-balancing, there is more than the usual danger that their decisions will be affected, consciously or not, by their personal preferences. Or by the preferences of a currently dominant political coalition. Or by views that are popular in the

\footnotetext{
59 See Lund, Proper Role, supra note 56, at 178-81.

${ }^{60}$ Heller II, 670 F.3d 1244, 1271 (D.C. Cir. 2011). Duncan v. Becerra invalidated a law providing for the confiscation of large-capacity magazines; although the opinion discusses history and tradition, the decision appears to rest on the application of strict scrutiny. 970 F.3d 1133, 1169 (9th Cir. 2020), petition for reh'g en banc granted, 988 F.3d 1209 (9th Cir. 2021).

${ }^{61}$ See Heller, 554 U.S. at 631-34.

62 Robert Leider, Our Non-Originalist Right to Bear Arms, 89 IND. L.J. 1587, 1619 (2014).

${ }^{63}$ For a critique of Judge Kavanaugh's reading of Heller, see Lund, Proper Role, supra note 56, at $190-92$.
} 
socioeconomic class to which most judges belong. Or by the opinions of the most strident voices in the media.

Where then should judges look for the guidance they need? Once one gets beyond total or nearly total bans on possessing or carrying weapons, the text of the Constitution does not offer much help. Nor do specific statements in the legislative history of the Second Amendment or the Fourteenth Amendment. A useful way to supplement these sources is by recurring to the fundamental principles on which our political regime was built. Those principles can help resolve questions that are left open by the constitutional text and legislative history because they illuminate the constitutional purposes the Second Amendment serves. Using these principles is analogous to (and in my view more defensible than) what the Supreme Court has done in its doctrine of Fourteenth Amendment incorporation, where the Court has sought guidance from fundamental principles that can be discerned in our nation's history and tradition. ${ }^{64}$

\section{THE PROMISE OF AMERICA’s LIBERAL REGIME}

Liberal republicanism as originally conceived rests on a doctrine of natural rights, the most fundamental of which is the right to self-defense. That right has little practical meaning without the tools one needs to defend oneself effectively. Hence the importance of the Second Amendment. But the first great theorist of natural rights was Thomas Hobbes, who recognized no valid constraint on the government's discretion to regulate or ban the possession of arms, even though he stressed the fundamental importance of the natural right to self-defense. His argument for empowering government with sweeping powers to restrict liberty in the interest of safety is perhaps the strongest that can be found in Anglo-American political philosophy. ${ }^{65}$

Hobbes began with the proposition that all human beings are free, in the absence of government, to do anything they think will help them to survive and prosper. That freedom includes the right to use force to eliminate real or imagined threats to their well-being. Because this state of nature is one of scarce resources, and because everyone has the same natural liberty to act on the natural aversion to death and sorrows, a war of all against all is the necessary consequence. Self-interested reason therefore tells everyone to agree to the establishment of an absolute sovereign (consisting of one or more individuals) whose own interest will be to maintain peace. Except for

\footnotetext{
${ }^{64}$ For brief discussions of the Court's incorporation jurisprudence, see Duncan v. Louisiana, 391 U.S. 145, 148-49, 149 n.14 (1968); Washington v. Glucksberg, 521 U.S. 702, 721 (1997); and McDonald v. City of Chicago, 561 U.S. 742, 758-59, 780-87 (2010) (plurality opinion).

65 For Hobbes's discussion of the concepts discussed in this paragraph and the next, see THOMAS HoBbes, LeVIATHAN, chs. 13-18 (London 1651).
} 
the right to resist forcible assaults, natural liberty must therefore be relinquished in exchange for the protection offered by the peace that the sovereign enforces. Any sovereign that prevents a lapse into the state of nature is preferable to the anarchy of that state. It follows, accordingly, that rational, self-interested obedience is owed to one's sovereign, however that ruler came to power and however he or they may rule.

Although no one openly defends Hobbes's theory of absolute sovereignty any longer, he remains unsurpassed in the clarity with which he illuminated the tension between liberty and safety and the centrality of government's role in establishing the terms of an inevitable trade-off between the two. Nor is his way of thinking extinct. Notwithstanding an apparent (and perhaps fragile) political consensus in favor of certain democratic procedures and certain personal freedoms, a strong commitment to principled limits on government power is far from universal in the United States today. And what commitment there is seems to be declining. In that sense, I believe, Hobbes is still with us, though in a veiled form. His political theory certainly supports the validity of highly restrictive gun regulations, but Hobbes's protoliberalism is not the liberalism of our Constitution.

John Locke rejected the Leviathan state and argued for the liberalism that we have inherited. He accepted Hobbes's claim that the preeminent human desire to live safely and prosper drives us to leave the state of nature by agreeing to the institution of political rule. ${ }^{66}$ At the same time, he identified a crucial flaw in Hobbes's logic, which led to Hobbes's mistaken endorsement of political absolutism. Because Hobbes thought that selfinterest would prompt sovereigns to promote peaceable relations among their subjects, he concluded that it is safer to trust the sovereign with absolute power than to risk a descent into anarchy or civil war. Locke acknowledged that political rulers would endeavor to prevent their subjects from killing one another, but he rejected the conclusion drawn by Hobbes and other defenders of absolute sovereignty: "This is to think that men are so foolish that they take care to avoid what mischiefs may be done them by polecats or foxes, but are content, nay, think it safety, to be devoured by lions." ${ }^{67}$

Locke laid the theoretical basis for rejecting Hobbes's political conclusions by denying that the exercise of self-interested reason necessarily leads to a war of all against all. On the contrary, he maintained, reason dictates natural laws that include a duty to refrain from harming others in their life, health, liberty, or possessions. ${ }^{68}$ This duty, in turn, implies an

\footnotetext{
66 John LOCKe, THE SECOND TREATISE OF GOVERNMENT, ch. 7, paras. $92-93$ (London 1689).

67 Id., ch. 7, para. 93.

${ }^{68} I d .$, ch. 2, para. 6.
} 
executive right in everyone, while in the state of nature, to enforce the natural law by punishing those who offend against it. ${ }^{69}$ Thus, although the state of nature is formally anarchic, it is not necessarily a state of war, let alone a war of all against all. ${ }^{70}$

In support of what our Declaration of Independence calls the unalienable rights to life, liberty, and the pursuit of happiness, Locke reasoned that a forcible attack on one's freedom or property, whether in the state of nature or in society, implies a design to take away everything else, including one's life. ${ }^{71}$ And that creates a state of war, even within society.

Thus a thief, whom I cannot harm but by appeal to the law for having stolen all that I am worth, I may kill when he sets on me to rob me but of my horse or coat; because the law, which was made for my preservation, where it cannot interpose to secure my life from present force, which, if lost, is capable of no reparation, permits me my own defense and the right of war, a liberty to kill the aggressor, because the aggressor allows not time to appeal to our common judge, nor the decision of the law, for remedy in a case where the mischief may be irreparable. ${ }^{72}$

According to Locke, the same reasoning that establishes the right to kill a robber also establishes the right to overthrow a predatory ruler. ${ }^{73}$ Prudence should no doubt regulate the exercise of both rights, as the Declaration of Independence acknowledges with respect to revolution, ${ }^{74}$ but that should not obscure the fundamental nature and common source of both rights.

Adam Smith, who rejected Locke's social contract theory, ${ }^{75}$ derived essentially the same understanding of natural rights and natural duty from his analysis of human psychology ${ }^{76}$ The same understanding, moreover, became a central element in our legal tradition. William Blackstone, the leading authority on English law for Americans of the Founding generation, ${ }^{77}$ echoed Locke and Smith. He stressed that when one's person or property is

69 Id., ch. 2, paras 7-8.

70 See id., ch. 2, para. 6, ch. 3, para. 19.

71 Id., ch. 3, paras. 17-18.

72 Id., ch. 3, para. 19.

73 See id., ch. 3, para. 19, ch. 7, paras. 93-94, ch. 13, para. 149.

74 The DeClaration OF INDEPENDENCE para. 2 (U.S. 1776) ("Prudence, indeed, will dictate that Governments long established should not be changed for light or transient causes .....”).

75 Adam Smith, Lectures on Jurisprudence: Report Dated 1776, in 5 THE GLASGOW EDITION OF THE Works AND CORRESPONDENCE OF ADAM SMith 395, 402-04 (R.L. Meek, D.D. Raphael \& P.G. Stein eds., 1978).

76 See Adam Smith, The Theory of Moral Sentiments, pt. 2, § 2, ch. 1, para. 7 (London 1759).

77 See, e.g., District of Columbia v. Heller, 554 U.S. 570, 593-94 (2008) (describing Blacksone's work as "constitut[ing] the preeminent authority on English law for the founding generation" (citation omitted)). 
forcibly attacked, nature itself prompts an immediate violent response because the future process of law may not offer an adequate remedy. "Selfdefence therefore, as it is justly called the primary law of nature, so it is not, neither can it be in fact, taken away by the law of society." 79

Blackstone's role in our tradition is especially notable because he linked this primary law of nature with the right to keep and bear arms, which he put among the indispensable auxiliary rights "which serve principally as barriers to protect and maintain inviolate the three great and primary rights, of personal security, personal liberty, and private property." 80 The right to arms, he said, is rooted in "the natural right of resistance and self-preservation, when the sanctions of society and laws are found insufficient to restrain the violence of oppression." "81 Blackstone made no distinction between the violence of oppression that results from government's failure to control criminals, including politically motivated rioters, and the oppression that government itself may undertake.

The shared understandings among Locke, Smith, and Blackstone reflect a view of natural rights and natural duty that provides the central and all-tooeasily-forgotten foundation of American liberalism. This understanding of correlative rights and duties is implicitly echoed in the structure of the Second Amendment, which is the constitutional provision that most directly addresses the most fundamental principle of our political order.

The Second Amendment links the right of self-defense against threats to personal safety with the right of self-defense against the threat of tyranny. The "right of the people to keep and bear Arms" is one that can be exercised by individuals to protect their own lives and liberty, or collectively to resist the imposition of despotism. Just as Locke insisted that there are natural duties along with natural rights, the Second Amendment refers to the wellregulated militia as an institution necessary to the security of a free state..$^{82}$ This reference is perfectly consistent with an individual right to arms because a well-regulated militia is, among other things, one that is not overly

\footnotetext{
783 WiLliam BLACKSTONE, COMMENTARIES *3-4.

${ }^{79} I d$. English law in Blackstone's time did not agree with Locke in all respects about the application of Lockean principles. See, e.g., $4 \mathrm{id}$. at *181-82 (discussing the narrower scope of justifiable homicide in English law compared with the state of nature).

$801 i d$. at $* 141$.

81 Id. at $* 144$.

82 See U.S. CONST. amend. II. The word "necessary" in the Second Amendment does not mean "absolutely necessary" any more than it has that meaning in the Sweeping Clause. $C f$. McCulloch v. Maryland, 17 U.S. (4 Wheat.) 316, 413-16 (1819) (explaining that the word does not automatically "import an absolute physical necessity").
} 
regulated or inappropriately regulated ${ }^{83}$ But the militia tradition did entail a legal duty of able-bodied men to undergo unpaid militia training and to fight when called upon to do so. ${ }^{84}$

Today, as a practical matter, the right to arms has less importance in protecting us from tyranny than it was thought to have in $1791 .^{85}$ But it has more importance in protecting us from criminal violence because government has become more aggressive in restricting our freedom to arm ourselves against this threat. The link in principle between the two is reflected in the Constitution's recognition that the militia may be required to take part in law enforcement as well as in suppressing insurrections and repelling invasions. ${ }^{86}$

The duty to help enforce the law was not traditionally confined to the militia context. As Stephen Halbrook reports, a vivid example occurred after the so-called Boston Massacre in 1770.87 When a crowd of colonists assaulted a group of British soldiers with death threats, hand-thrown missiles, clubs, and a sword, the soldiers fired their weapons, killing five and wounding six. At the soldiers' trial for unlawful homicide, the only issue was whether the civilians or the soldiers were the aggressors. ${ }^{88}$

One of the prosecutors emphasized that Bostonians had every right to arm themselves with lethal weapons as a defense against soldiers who had a record of abusive treatment. As counsel for the defendants, John Adams emphasized the soldiers' own right of self-defense, "the primary Canon of the Law of Nature," but he also acknowledged that the colonists had the right to arm themselves. Significantly, the court's charge to the jury pointed out a duty that would also have justified civilians in arming themselves that night:

It is the duty of all persons (except women, decrepit persons, and infants under fifteen) to aid and assist the peace officers to suppress riots \& c. when called

\footnotetext{
83 See Nelson Lund, The Ends of Second Amendment Jurisprudence: Firearms Disabilities and Domestic Violence Restraining Orders, 4 TEX. Rev. L. \& PoL. 157, 175-76 (1999); Lund, D.C.'s Handgun Ban, supra note 30, at 241-44.

84 See Malcolm, supra note 16, at 138-39; Act of May 8, 1792, ch. XXXIII, § 1, 1 Stat. 271, 271.

85 For further discussion of the relation between the Second Amendment and the threat of tyranny, see Lund, Past and Future, supra note 30, at 30-34, 56-58; Lund, Originalist Jurisprudence, supra note 29 , at $1373-74$.

86 See U.S. CONST. art. I, § 8, cl. 15.

87 STEPHEN P. HALBRoOK, THE Founders' SECOND AMENDMENT: ORIGINS OF THE Right TO BEAR ARMS 24-25 (updated ed. 2019).

${ }^{88}$ See id. at 24.
} 
upon to do it. They may take with them such weapons as are necessary to enable them effectually to do it. ${ }^{89}$

This was a legal duty, not just an aspiration. American colonies had laws requiring citizens to possess firearms and to carry them in certain circumstances..$^{90}$ Our laws no longer require citizens to undergo militia training or to arm themselves against threats posed by violent mobs and other criminals. ${ }^{91}$ In one obvious sense, these changes have made us more free. But the freedom to rely entirely on the government for protection against criminal violence also has the potential to undermine our liberty. The Second Amendment helps to discourage a decadent overreliance on the state.

Everyone knows or should know that the government could not come close to eliminating criminal violence without imposing an intolerably harsh and pervasive system of policing on the population. It seems to be less widely appreciated that our most privileged citizens have very little exposure to violent crime. That is certainly true of government officials who are protected by armed guards ${ }^{92}$ and of anyone wealthy enough to hire professional security services. More broadly, most upper-middle-class people live and work in very safe environments. To impose useless or counterproductive restrictions on firearms (or other weapons useful for self-

89 Id. at 24-25 (quoting John Adams, No. 64. Rex v. Wemms, 1770, in 3 LEGAL PAPERS OF JOHN ADAMS 98, 285 (L. Kinvin Wroth \& Hiller B. Zobel eds., 1965)). The judge was referring to the posse comitatus, which is discussed by Blackstone. See 1 BLACKSTONE, supra note 78, at *243; $4 \mathrm{id}$. at *147.

${ }^{90}$ See Don B. Kates, Jr., Handgun Prohibition and the Original Meaning of the Second Amendment, 82 Mich. L. REV. 204, 215-16 (1983); MALCOLM, supra, note 16, at 138-41.

91 The law does, however, continue to recognize the principle that citizens may be called on to fight. Almost all men between the ages of seventeen and forty-four are enrolled by operation of law in the militia. 10 U.S.C. $\S 246$. And most young men are required to register with the government in case a military draft is reinstituted. 50 U.S.C. $\$ 3802$.

92 See, e.g., Citing Threats, Mayor Defends Police Presence, Protest Restrictions at Her Home, NBC CHI. (Aug. 20, 2020, 6:36 PM), https://www.nbcchicago.com/news/local/citing-threats-mayor-defendspolice-presence-protest-restrictions-at-her-home/2325754/ [https://perma.cc/M6AN-9FAZ] (discussing the police presence outside the mayor of Chicago's home following alleged threats to her family). Some of the mayors who initially tolerated riots in their cities during the summer of 2020 assumed a different attitude after they were threatened with demonstrations at their own homes. See Doug Trumm, Mayor Durkan Launches Offensive Against Sawant and CHOP After Protest Outside Her Home, URBANIST (July 1, 2020), https://www.theurbanist.org/2020/07/01/mayor-durkan-launches-offensive-against-sawantand-chop-after-protest-outside-her-home/ [https://perma.cc/6DY8-VAKN]; Dom Calicchio, Washington State Mayor Now Calls BLM Protests 'Domestic Terrorism' After Her Home Vandalized, Fox News (June 18, 2020), https://www.foxnews.com/us/washington-state-mayor-now-calls-blm-protestsdomestic-terrorism-after-her-home-vandalized [https://perma.cc/LP45-KXLY].

Some government officials recognize how privileged they are. See, e.g., Peruta v. California, $137 \mathrm{~S}$. Ct. 1995, 1999-2000 (2017) (Thomas, J., dissenting from the denial of certiorari) ("For those of us who work in marbled halls, guarded constantly by a vigilant and dedicated police force, the guarantees of the Second Amendment might seem antiquated and superfluous. But the Framers made a clear choice: They reserved to all Americans the right to bear arms for self-defense."). 
defense ${ }^{93}$ ) in the name of making people who are already quite safe feel more secure is to privilege their preferences over the actual physical safety of less fortunate citizens who are likely made more vulnerable to violent crime. Such feelings should be given no weight at all in the constitutional interestbalancing that judges frequently must perform. And yet, it happens. Writing for the Seventh Circuit, for example, Judge Frank Easterbrook relied in part on the following argument in upholding a gun-control regulation:

If it has no other effect, Highland Park's ordinance may increase the public's sense of safety. Mass shootings are rare, but they are highly salient, and people tend to overestimate the likelihood of salient events. If a ban on semiautomatic guns and large-capacity magazines reduces the perceived risk from a mass shooting, and makes the public feel safer as a result, that's a substantial benefit. ${ }^{94}$

Even when there is good reason to estimate that a regulation would cause a net reduction in deaths and injuries, such calculations are not a sufficient basis on which to uphold the regulation's constitutionality. Fundamental principles of our regime, articulated by Locke and Blackstone and confirmed in the Second Amendment, have two related implications. First, I do not lose my right to the means of protecting myself merely because others are vulnerable to violent attacks, whether through their own choices or through bad luck. Second, the rejection of Hobbesian absolutism in favor of political self-government depends for its ultimate success on citizens who possess the moral temper befitting a free people. Citizens who arm themselves are recognizing and insisting that their lives and safety are not a gift from the government, and they claim responsibility for their own freedom and security.

The clarity with which Locke and Blackstone articulated fundamental liberal principles does not imply that English law has ever fully reflected those principles. Nor does the English heritage of the Second Amendment imply that the meaning of our Constitution is confined within the scope given to the right to arms in English law. The relevance of Blackstone in understanding the American right to arms, for example, lies primarily in his prominence as an exponent of the natural right of self-defense, rather than as

\footnotetext{
93 For a discussion on nonlethal weapons, see Craig S. Lerner \& Nelson Lund, Heller and Nonlethal Weapons, 60 HASTINGS L.J. 1387, 1389 (2009).

94 Friedman v. City of Highland Park, 784 F.3d 406, 412 (7th Cir. 2015) (citation omitted), cert. denied, 136 S. Ct. 447. Justice Thomas, joined by Justice Scalia, dissented from the Supreme Court's denial of certiorari.
} 
an expositor of the details of English law. ${ }^{95}$ We have, of course, always been forbidden to commit a common law assault by threatening to use force against another person without a legal justification. And there are no doubt many cases where it is unclear whether such a threat has been made. ${ }^{96}$ But subjective discomfort at the sight or thought of weaponry does not come close to making one a victim of assault. ${ }^{97}$

In addition to its other contributions to civil liberty, the Second Amendment also provides a barrier against the kind of tyranny that arises when governments acquiesce in political violence by private groups..$^{98}$ The Jim Crow period offers the most prominent example of that phenomenon in our history. The politically motivated riots of our time also produce a kind of informal tyranny, notwithstanding important differences in the scale of the oppression and in the motivations of the rioters and the government officials who tacitly encourage them. We are obviously a very long way from anything like an ascendant Ku Klux Klan or another Colfax Massacre, ${ }^{99}$ but we are not necessarily immune from serious government efforts to disarm citizens who are threatened by political violence. After Hurricane Katrina, the government tried to disarm a civilian population that was threatened by common criminals during a collapse of civil order. ${ }^{100}$ How much more

95 The English Bill of Rights, for example, provided that "the Subjects which are Protestants may have Arms for their Defence suitable to their Conditions and as allowed by Law." 1 W. \& M., 2d Sess., ch. 2, § 7 (1688), in 6 THE StatuTeS of THE REALm 143. It is self-evident that the Second Amendment is considerably broader than this analogue, as James Madison stressed when he made his initial proposal for our Bill of Rights to the House of Representatives. 1 ANNALS OF CONG. 453 (1789) (Joseph Gales ed., 1834).

${ }^{96}$ See, e.g., Joseph Blocher, Samuel W. Buell, Jacob D. Charles \& Darrell A.H. Miller, Pointing Guns, 99 TEX. L. REV. 1173, 1173-74 (2021) (providing examples of incidents in which it was unclear whether armed civilians were legally justified in displaying their weapons).

97 See, e.g., 2 JoEl PRENTISS Bishop, COMMENTARIES ON THE CRIMINAL LAW $\$ 34$ (4th ed., Boston, Little, Brown, \& Co. 1868) (explaining that the ancient Anglo-American prohibition against going armed to the terror of the people requires more than mere arming and should be understood to mean that "what is done must sustain the same relation to an actual fighting, which an assault does to a battery").

98 Cf. Patrick M. Garry, The Second Amendment as a Guard Against Government-Sanctioned Tyrannous Factions 1 (Liberty \& L. Ctr. Research Paper No. 20-06, 2020) https://papers.ssrn.com/ $\mathrm{a}=3712308$ [https://perma.cc/KD5B-R5E7] (arguing that individual self-defense "remains a necessary check on violent factions allied with corrupt local government").

99 The Colfax Massacre gave rise to the Cruikshank case. McDonald v. City of Chicago, 561 U.S. 742,757 (2010) (recounting that, in 1873, "[d]ozens of blacks, many unarmed, were slaughtered by a rival band of armed white men"); id. at 808-09 (Thomas, J., concurring in part and concurring in the judgment).

100 See, e.g., Alex Berenson \& John M. Broder, Police Begin Seizing Guns of Civilians, N.Y. TIMES (Sept. 9, 2005), https://www.nytimes.com/2005/09/09/us/nationalspecial/police-begin-seizing-guns-ofcivilians.html [https://perma.cc/E7WK-386Q] (reporting that "after a week of near anarchy in the city, no civilians in New Orleans will be allowed to carry pistols, shotguns, or other firearms of any kind"); Stephen P. Halbrook, "Only Law Enforcement Will Be Allowed to Have Guns": Hurricane Katrina and 
tempting might it be to disarm a population threatened by political extremists pursuing aims with which many government officials sympathize?

The U.S. Court of Appeals for the Ninth Circuit has laid the basis for just such disarmament. Several years ago, that court held that the Second Amendment does not protect the right to carry a concealed weapon in public. ${ }^{101}$ In early 2021, the court held, in Young v. Hawaii, that the same is true of carrying weapons openly. ${ }^{102}$ Together, these two decisions permit the government to forbid anyone or everyone to carry a weapon for self-defense anywhere except within their home.

Writing for seven members of the Young court, Judge Jay S. Bybee relied on a supposed tradition of total governmental control over public spaces. ${ }^{103}$ The centerpiece of Young's argument is the 1328 Statute of Northampton, which provided in part that all English subjects were forbidden

to come before the King's Justices, or other of the King's Ministers doing their office, with force and arms, nor bring no force in affray of the peace, nor to go nor ride armed by night nor by day, in Fairs, Markets, nor in the presence of the Justices or other Ministers, nor in no part elsewhere. ${ }^{104}$

Taken literally, this law could be read as an absolute prohibition against carrying a weapon in public. After tracing the Statute's legacy through English and American history, Young finally concludes:

[F]or centuries we have accepted that, in order to maintain the public peace, the government must have the power to determine whether and how arms may be carried in public places. There is no right to carry arms openly in public; nor is any such right within the scope of the Second Amendment." 105

the New Orleans Firearms Confiscations, 18 GEO. MASON U. C.R.L.J. 339, 339 (2008) ("Police proceeded to seize frearms at gunpoint .... Citizens were left without protection in a city besieged by looters and criminals.").

101 Peruta v. County of San Diego, 824 F.3d 919, 924 (9th Cir. 2016) (en banc).

102992 F.3d 765, 773 (9th Cir. 2021) (en banc), petition for cert. filed, No. 20-1639 (May 25). In order to obtain a license to carry a firearm openly under the challenged statute, a resident must demonstrate "the urgency or the need" to do so, must be of "good moral character," and must be "engaged in the protection of life and property"; if those criteria are satisfied, the chief of police "may" issue a license. Id. at 773, 775 (quoting HAW. REV. STAT. § 134-9(a) (2019)).

$103 I d$. at 813 . As published by the Ninth Circuit, the majority opinion is over 100 pages long. The principal dissent, written by Judge Diarmuid F. O'Scannlain for four members of the court, criticizes the majority in more detail than I have space to provide in this Essay. See Young v. Hawaii, No. 12-17808, slip op. at 128-94 (9th Cir. Mar. 24, 2021) (O'Scannlain, J., dissenting), https://www.govinfo.gov/ content/pkg/USCOURTS-ca9-12-17808/pdf/USCOURTS-ca9-12-17808-2.pdf [https://perma.cc/HXE4KW4N].

1042 Edw. 3, ch. 3 (1328), in 1 The Statutes of the Realm 258.

105 Young, 992 F.3d at 821. 
The argument seems to be that government has a long-established absolute authority to forbid the carrying of weapons in public and thus that a right to do so was not within the "pre-existing" right that Heller said was codified by the Second Amendment. ${ }^{106}$

This argument is fallacious at best. Heller's reference to the codification of a "pre-existing" right cannot possibly refer to anything except the right as it existed in the United States in 1791. However the Statute of Northampton may have been interpreted in England, ${ }^{107}$ American law did not recognize an absolute authority of the government to prohibit bearing weapons in public. This is illustrated by several early state laws that were analogous to the Statute of Northampton. Each one of them included an express qualification that was not in the English text. ${ }^{108}$ Virginia (1786), for example, prohibited going or riding armed "in terror of the Country"; Tennessee (1801) prohibited going armed "to the terror of the people"; Massachusetts (1795) and Maine (1821) authorized the arrest of people who "ride or go armed offensively, to the fear or terror of the good citizens." 109 No one could honestly think that these statutes forbade American citizens to step out of their homes while carrying a gun. ${ }^{110}$

Not surprisingly, the case law is similarly bereft of support for Young's claim that the Second Amendment codified a long tradition of total government control over carrying weapons in public. The court does not cite a single case declaring, let alone holding, that the individual right protected

\footnotetext{
106 See id.at 786

107 There is little evidence that the Statute of Northampton was enforced according to a broad literal interpretation. See, e.g., MALCOLM, supra note 16, at 102-06 (maintaining that the Statute had never been enforced until James II made a failed attempt to use it against a political dissident); STEPHEN P. Halbrook, The Right to Bear ARMS: A Constitutional Right of the People or a Privilege of THE RULING ClASS? 42-58 (2021) (providing a detailed discussion of James II's use of the Statute of Northampton as a political weapon); David B. Kopel \& George A. Mocsary, Errors of Omission: Words Missing from the Ninth Circuit's Young v. Hawaii, 2021 U. ILL. L. REv. ONLINE 172, 175-78 (accusing the Young court of misrepresenting the two seventeenth-century judicial opinions it cited on the enforcement issue).

108 Young claims that in 1792 North Carolina reenacted the English Statute almost verbatim, including its references to the King. 992 F.3d at 798. This is probably not true. See Kopel \& Mocsary, supra note 107 , at $182-83$. Even if it is true, the statute would be so patently absurd that it could not have been enforced.

109 These statutes are quoted in Young, 992 F.3d at 796, 798-99.

110 Nineteenth-century treatises confirm this obvious fact, as Young's own survey shows. See id. at 809-11; cf. 5 St. GEORGE TUCKER, BlaCKSTONE's COMmENTARIES, app. n.B at 19 (Philadelphia, Wm. Young Birch \& Abraham Small 1803) ("In many parts of the United States, a man no more thinks, of going out of his house on any occasion, without his rifle or musket in his hand, than an European fine gentleman without his sword by his side.”); Moore v. Madigan, 702 F.3d 933, 936 (7th Cir. 2012) (“[O]ne doesn't have to be a historian to realize that a right to keep and bear arms for personal self-defense in the eighteenth century could not rationally have been limited to the home.").
} 
by the Second Amendment could lawfully be taken away by a general ban on carrying weapons in public. ${ }^{111}$

Lacking any actual evidence that the Second Amendment was understood to permit a general ban on bearing arms in public in 1791, the Young court seems in the end to rest its decision on the following propositions:

Notwithstanding the advances in handgun technology, and their increasing popularity, pistols and revolvers remain among the class of deadly weapons that are easily transported and concealed. That they may be used for defense does not change their threat to the "king's peace." It remains as true today as it was centuries ago, that the mere presence of such weapons presents a terror to the public and that widespread carrying of handguns would strongly suggest that state and local governments have lost control of our public areas. Technology has not altered those very human understandings. ${ }^{112}$

The court's reference to the "king's peace" is both anachronistic and anachoristic. We Americans thought we had freed ourselves from British monarchs almost two and a half centuries ago. Do these judges really believe that American citizens can reasonably complain that they are terrorized by the mere presence of handguns in public? On what basis could "th[e]se very human understandings" (which might better be characterized as irrational misunderstandings) possibly justify the legal conclusion that "no right to carry arms openly in public... [is] within the scope of the Second Amendment"? ${ }^{113}$

111 See Young, 992 F.3d at $802-08$. This is confirmed by the court's own summary of the cases. Id. at 808 (admitting that even the most severe restrictions are not total bars but rather forbid "open carrying in certain places," "open carrying of certain types of firearms or weapons," or "open carrying without a license"). Young tries to bolster its argument with references to nineteenth-century surety laws. See id. at 819-20. Those statutes do not support the court's conclusion. See id. at 844-45 (O'Scannlain, J., dissenting); Robert Leider, Constitutional Liquidation, Surety Laws, and the Right to Bear Arms, in NEW HISTORIES OF GUN RIGHTS AND REGULATIONS: ESSAYS ON THE PLACE OF GUNS IN AMERICAN LAW AND SOCIETY (Joseph Blocher, Jacob D. Charles \& Darrell A.H. Miller eds., forthcoming) (refuting the claim that nineteeth-century surety laws are evidence that "historically the constitutional protection for the right to bear arms coexisted with severe limitations on public carry"); Stephen P. Halbrook, Faux Histoire of the Right to Bear Arms: Young v. Hawaii (9th Cir. 2021) (Jul. 13, 2021) (unpublished manuscript), https://papers.ssrn.com/a=3885910 [https://perma.cc/U3YM-6H2J] (providing a detailed critique of Young's use of historical sources).

112 Young, 992 F.3d at 821.

$113 I d$. The Hawaii statute at issue in the case does not by its terms impose an absolute ban on carrying any kind of weapon in public. See HAW. REV. STAT. § 134-9(a) (2019). Under circuit precedent, Hawaii’s restrictions would be unconstitutional if they amounted to a destruction of the core Second Amendment right. See Silvester v. Harris, 843 F.3d 816, 821 (9th Cir. 2016). Even if they merely imposed a severe burden on the right, they would be subject to strict scrutiny. Id. Young avoided applying this precedent by ruling that no such right even exists. For that reason, the holding in the case cannot be confined to the 
The Young court's ipse dixit, akin in spirit to Judge Easterbrook's solicitude for the feelings of people who "overestimate the likelihood of salient events," shows one way in which the Supreme Court could begin to limit Heller to its facts. Perhaps it is unlikely that the Justices would go as far as the Young court did when it effectively expunged the words "and bear" from the Constitution. ${ }^{114}$ But the Court could accomplish the same practical result by upholding laws that give government officials the discretion to forbid almost everyone to carry weapons in public. Several courts have already done exactly that. ${ }^{115}$

In a chilling excursion into the realm of political philosophy, Young offered the following comment:

Defense of the public square stands on entirely different footing [from defense of the home]. "One of the first duties of government is to [ ] afford protection." Marbury v. Madison, 5 U.S. (1 Cranch) 137, 163, 2 L.Ed. 60 (1803). Indeed, among the fundamental privileges of citizenship in the United States is "[p]rotection by the government." Corfield v. Coryell, 6 F. Cas. 546, 551 (C.C.E.D. Pa. 1823) (No. 3230). Protection is the quid pro quo for our allegiance to the government. As Blackstone explained, "the community should guard the rights of each individual member, and... (in return for this protection) each individual should submit to the laws of the community; without which submission of all it was impossible that protection could be certainly extended to any." 1 William Blackstone, Commentaries at *47-48; see also Calvin's Case (1609), 77 Eng. Rep. 377, 382 (K.B.) (Coke, J.) (stating that "the Sovereign is to govern and protect his subjects" and "the subject oweth to the King his true and faithful ligeance"); English, 35 Tex. at 477 ("It is useless to talk about personal liberty being infringed by laws such as that under

specific restrictions in the Hawaii statute. In any event, the Young opinion gives no examples of statutes closely analogous to the Hawaii statute from the relevant time period, i.e., circa 1791. 992 F.3d at 79798.

114 At two points in the Young opinion, the court seems to assume that "bear Arms" in the Constitution could mean something other than to carry them in public, but the court never says what that might be. See 992 F.3d at 782-83, 813.

115 See, e.g., Gould v. Morgan, 907 F.3d 659, 674 (1st Cir. 2018) (upholding statute requiring "a heightened need to carry firearms for self-defense and allow[ing] local licensing authorities to take a caseby-case approach in deciding whether a particular "applicant has good reason to fear injury" (quoting MASS. GEN. LAwS ch. 140, § 131(d) (2018))); Drake v. Filko, 724 F.3d 426, 429-30 (3d Cir. 2013) (requiring "justifiable need"); Woollard v. Gallagher, 712 F.3d 865, 876 (4th Cir. 2013) (requiring a good and substantial reason); Kachalsky v. County of Westchester, 701 F.3d 81, 83-84 96-97 (2d Cir. 2012) (requiring proper cause, i.e., "a special need for self-protection"). The Supreme Court recently agreed to review the issue raised by such decisions. N.Y. State Rifle \& Pistol Ass'n v. Bruen, No. 20-843 (U.S. Apr. 26, 2021), https://www.supremecourt.gov/search.aspx?filename=/docket/docketfiles/html/public/ 20-843.html [https://perma.cc/V2JA-ME2E] (granting petition for certiorari that challenges the constitutionality of a statute requiring an applicant for a license to carry a firearm to satisfy a licensing officer that the applicant, among other things, is of good moral character and lacks a history of crime or mental illness, and that no good cause exists for the denial of the license). 
consideration. The world has seen too much licentiousness cloaked under the name of natural or personal liberty; natural and personal liberty are exchanged, under the ... social compact of states, for civil liberty.”). The king who cannot guarantee the security of his subjects - from threats internal or external - will not likely remain sovereign for long. ${ }^{116}$

Our governments, the Ninth Circuit tries to teach us, are closely analogous to the king referred to in the last sentence of this quotation. The American people, who might once have thought they were the sovereign, should completely trust the government to protect their safety because the alternative is anarchy or civil war. That is Hobbes in a nutshell, and the court's preposterously inapt citations to impressive authorities like Blackstone and Lord Coke cannot conceal the Hobbesian message. It is shocking to see this in an American judicial opinion, and it is appalling to see it appear during a time when many of our local "kings" abdicated their duty to protect the public square.

Whatever English law may have permitted the King to do, we Americans do not surrender our right to freedom of speech simply because many people (maybe all of us) are sometimes offended by its exercise. We do not surrender the right even when the abuse of that liberty by our fellow citizens results in significant social harm. As it frequently does. A healthy skepticism about the beneficence of government power has also preserved the panoply of procedural protections in the Bill of Rights. The protection of rights like those in the Fourth Amendment and the Fifth Amendment's Due Process of Law Clause undoubtedly leads to some amount of death and destruction, perhaps a considerable amount, that would not occur if more aggressive law enforcement techniques were authorized. ${ }^{117}$ The Supreme Court does not cater to those who would feel safer if they were protected from speech that corrupts the culture in which we live. Nor does the Court accede to the wishes of those who would like to see rough justice administered to politically unpopular targets. It should show no more deference to those who fear the civic spirit displayed by an armed citizenry.

The misconduct of government officials who tolerate or encourage violent riots should be a reminder that the state of nature is not quite so remote from our everyday lives as we usually assume it is. That reminder will no doubt be interpreted differently by those who share Hobbes's

116 Young, 992 F.3d at 814 (internal alterations omitted).

117 This possibility has not escaped the Supreme Court's attention. See, e.g., McDonald v. City of Chicago, 561 U.S. 742, 783 (2010) (plurality opinion) ("The right to keep and bear arms, however, is not the only constitutional right that has controversial public safety implications. All of the constitutional provisions that impose restrictions on law enforcement and on the prosecution of crimes fall into the same category."). 
diffident spirit than by those who lean toward the obstinate self-reliance of Locke. But it is the spirit of Locke, not Hobbes, that animates our Constitution. Whatever their own "very human understandings" may be, our judges have a duty to resist treating civil unrest, or high crime rates more generally, as a justification for diluting or undermining the constitutional right of the people to keep and bear arms. And the Supreme Court has a duty to correct the lower courts when they substitute their personal understandings for the law.

\section{CONCLUSION}

Professors Reva B. Siegel and Joseph Blocher have rightly urged that debates about the constitutionality of gun-control regulations be informed by an appropriately broad concept of public safety. I agree that narrow costbenefit analyses that ask only about the net effects on deaths and physical injuries reflect an impoverished view of the public interest. Unlike Professors Siegel and Blocher, however, I maintain that the richer view implied by the Constitution should make courts especially skeptical of infringements on the freedom to keep and bear arms, even when such infringements might in the short term have net positive effects in terms of deaths and injuries.

The single most foundational principle on which our liberal regime was established is the inherent right of self-defense against violent assaults, whether from common criminals or political activists or tyrannical governments. The Second Amendment's core purpose is to insulate that right from improper government interference. But protecting the right also serves a broader civic purpose. An armed citizenry exemplifies the spirit of courage and self-reliance on which genuine self-government depends. That spirit should be honored more than ever in times of civil unrest, and especially when governments have responded passively or with perverse encouragement to mob violence.

Justice Stevens was right when he said: "Your interest in keeping and bearing a certain firearm may diminish my interest in being and feeling safe from armed violence." 118 But he was wrong to advocate that the Second Amendment be repealed in order to ensure that the government's interest in helping those like him to feel safe will always take precedence in court. ${ }^{119}$ It is equally wrong to suggest that violent crime, or widespread civic turmoil, provides any justification for relaxing the Second Amendment's strong presumption against infringements of the freedom to keep and bear arms. If

\footnotetext{
118 See id. at 891 (Stevens, J., dissenting); supra text accompanying note 1.

119 See supra note 2.
} 
116:81 (2021) The Future of the Second Amendment in a Time of Lawless Violence

anything, flaccid government responses to violent mobs should make judges more skeptical than ever about restrictions on the liberty of those whom the government cannot or will not protect. 
NORTHW ESTERN UNIVERSITY L A W RE VIEW 